\title{
Potential of phenolic extracts from Brewer's spent grain to protect against oxidant-induced DNA damage
}

\author{
A. L. McCarthy ${ }^{1}$, Y. C. O'Callaghan ${ }^{1}$, C. O. Piggott ${ }^{2}$, R. J. FitzGerald ${ }^{2}$ and N. M. O’Brien ${ }^{1}$ \\ ${ }^{1}$ School of Food and Nutritional Sciences, University College Cork, Ireland and ${ }^{2}$ Department of Life Sciences, University of \\ Limerick, Ireland
}

Brewers' spent grain (BSG), the residual solid fraction of barley malt remaining after the production of wort, contains relatively high amounts of phenolic acids including ferulic acid, p-coumaric acid, sinapic acid and caffeic acid ${ }^{(1)}$. BSG has the potential to be utilised as a valuable source of antioxidant, anti-inflammatory and anti-carcinogenic compounds ${ }^{(2)}$. The objective of the study was to establish the in vitro antioxidant effect of these extracts using U937, human leukaemic cell line.

Four extracts were prepared from both pale (P1-P4) and dark (B1-B4) BSG. Extract 1 was an aqueous extract of BSG and contained free phenolics. Extract 2 was extracted from BSG sediment, following protein extraction, using $1 \mathrm{M}$ NaOH which releases bound phenolics. Extract 3 was an aqueous wash of the sediment used for extract 2 and contained the remaining bound phenolics. Extract 4 was the supernatant from a $110 \mathrm{mM} \mathrm{NaOH}$ protein extract of $\mathrm{BSG}$ and contains the phenolics that are extracted at this $\mathrm{NaOH}$ concentration. The total phenol content of each of the extracts was measured. U937 cells were treated with increasing concentrations of the phenolic extracts for $24 \mathrm{~h}$ and the MTT assay was used to determine cell viability. DNA damage in U937 cells was evaluated by the comet assay, following pre-treatment of the cells with $2.5 \%(\mathrm{v} / \mathrm{v}) \mathrm{BSG}$ extracts or $1 \mu \mathrm{g} / \mathrm{ml}$ ferulic acid for $24 \mathrm{~h}$ and subsequent exposure of the cells to $50 \mu \mathrm{M} \mathrm{H}_{2} \mathrm{O}_{2}$ for $30 \mathrm{~min}$.

\begin{tabular}{lccccc}
\hline & \multicolumn{2}{c}{ DNA damage $(\%$ tail DNA) } & \multicolumn{3}{c}{ DNA damage (\% tail DNA) } \\
\cline { 2 - 5 } & \multicolumn{1}{c}{ Mean } & SE & Mean & SE \\
\hline Control & 3.2 & 0.5 & Control & 2.6 & 0.3 \\
$\mathrm{H}_{2} \mathrm{O}_{2}$ & 40.3 & 0.3 & $\mathrm{H}_{2} \mathrm{O}_{2}$ & 42.1 & 2.7 \\
$\mathrm{P} 1$ & 30.3 & $\mathrm{~B} 1$ & $25.8^{*}$ & 7.5 \\
$\mathrm{P} 2$ & 29.0 & 6.0 & $\mathrm{~B} 2$ & $9.6^{*}$ & 1.1 \\
$\mathrm{P} 3$ & 29.9 & 3.9 & $\mathrm{~B} 3$ & $16.0^{*}$ & 2.0 \\
$\mathrm{P} 4$ & 23.1 & $\mathrm{~B} 4$ & $14.0^{*}$ & 3.8 \\
$\mathrm{FA}$ & $20.3^{*}$ & 5.7 & $\mathrm{FA}$ & $17.1^{*}$ & 0.8 \\
\hline Values are mean of three independent experiments. Statistical analysis was by ANOVA followed by Dunnett's test.
\end{tabular}

Values are mean of three independent experiments. Statistical analysis was by ANOVA followed by Dunnett's test.

*Denotes significant difference $(P<0.05)$ in DNA damage, relative to $\mathrm{H}_{2} \mathrm{O}_{2}$ control.

The total phenol content of P1, P2, P3 and P4 was $0.058,0.533,0.294$ and $0.123 \mathrm{mg}$ gallic acid equivalents (GAE)/ml, respectively. The total phenol content of B1, B2, B3 and B4 was $0.083,0.732,0.267$ and $0.128 \mathrm{mg} \mathrm{GAE} / \mathrm{ml}$, respectively. The addition of $50 \mu \mathrm{M} \mathrm{H}_{2} \mathrm{O}_{2}$ for 30 min significantly increased $(P<0.05)$ tail DNA to approximately $40 \%$ in U937 cells. The pale BSG extracts failed to significantly protect $(P<0.05)$ against the oxidant induced DNA damage. However, all of the dark BSG extracts provided significant protection $(P<0.05)$ against the damage induced by $\mathrm{H}_{2} \mathrm{O}_{2}$. In conclusion, it was shown that the dark $\mathrm{BSG}$ extracts show greatest antioxidant potential in U937 cells. Given that these extracts were found to have higher total phenol content than the corresponding pale BSG samples, a relationship between polyphenol concentration and protection against oxidant-induced DNA damage is evident.

Funding for this research was provided under the National Development Plan, through the Food Institutional Research Measure, administered by the Department of Agriculture, Fisheries and Food, Ireland.

1. Szwajgier D, Wasko A, Targonski Z et al. (2010) J Inst Brew 116, 293-303.

2. Yang CS, Landau JM, Huang M-T et al. (2001) Annu Rev Nutr 21, 381-406. 